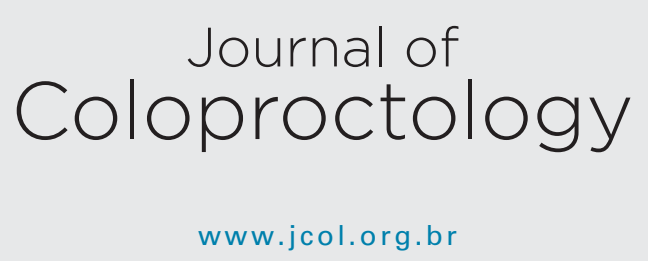

Case Report

\title{
A novel approach for rectal trauma. The use of a transanal platform to repair a combined high-velocity rectal gun fire wound
}

\author{
Montserrat Guraieb-Trueba (1) ${ }^{a, *}$, Juan Carlos Sánchez-Robles ${ }^{a}$, \\ Oscar Enrique Pérez-Morales ${ }^{b}$, Luis Manuel García-Núñez ${ }^{b}$ \\ a Secretaría de la Defensa Nacional México, Hospital Central Militar, Colorectal Surgery Department, Ciudad de México, Mexico \\ b Secretaría de la Defensa Nacional México, Hospital Central Militar, Trauma Surgery Department, Ciudad de México, Mexico
}

\section{A R T I C L E I N F O}

\section{Article history:}

Received 8 December 2019

Accepted 13 January 2020

Available online 23 January 2020

Keywords:

Trauma

Rectum

Gunfire wound

Transanal

\begin{abstract}
A B S T R A C T
Up to $80 \%$ of the rectal injuries reported in US trauma centers occur secondary to firearm injuries. Rectal gunshot wounds are associated with significant morbidity and mortality. Diverse surgical approaches and techniques have been described; however, controversy persists regarding the best management for these complex injuries. Nowadays, no single approach has proven to provide optimal results when dealing with these injuries. We present a case of a young male that suffered a combined (intra-extraperitoneal) gun shot gun to the rectus and the use of a transanal platform to repair it.

(c) 2020 Sociedade Brasileira de Coloproctologia. Published by Elsevier Editora Ltda. This is an open access article under the CC BY-NC-ND license (http://creativecommons.org/ licenses/by-nc-nd/4.0/).
\end{abstract}

\section{Uma nova abordagem para trauma retal. Uso de uma plataforma transanal para reparo de ferimento retal combinado por disparo de arma de fogo de alta velocidade}

R E S U M O

Até $80 \%$ das lesões retais relatadas nos centros de trauma dos EUA ocorrem secundariamente às lesões por armas de fogo. Ferimentos retais por arma de fogo estão associados a significativa morbimortalidade. Foram descritas diversas abordagens e técnicas cirúrgicas; no entanto, ainda há controvérsias quanto qual é o melhor tratamento para essas lesões complexas. Atualmente, nenhuma abordagem isolada provou ótimos resultados ao lidar com essas lesões. Apresentamos um caso de um jovem do sexo masculino que sofreu um
Palauras-chave:

Trauma

Reto

Ferida de arma de fogo

Transanal

\footnotetext{
* Corresponding author.

E-mail: Mguraieb16@hotmail.com (M. Guraieb-Trueba).

https://doi.org/10.1016/j.jcol.2020.01.002

2237-9363/@ 2020 Sociedade Brasileira de Coloproctologia. Published by Elsevier Editora Ltda. This is an open access article under the CC BY-NC-ND license (http://creativecommons.org/licenses/by-nc-nd/4.0/).
} 
ferimento de pistola combinada (intra-extraperitoneal) no reto e o uso de uma plataforma transanal para repará-la.

(c) 2020 Sociedade Brasileira de Coloproctologia. Publicado por Elsevier Editora Ltda. Este

é um artigo Open Access sob uma licença CC BY-NC-ND (http://creativecommons.org/ licenses/by-nc-nd/4.0/).

\section{Introduction}

Up to $80 \%$ of the rectal injuries reported in US trauma centers occur secondary to firearm injuries. Rectal gunshot wounds are associated with significant morbidity and mortality. The anatomic location of the injury, intraperitoneal versus extraperitoneal, has a major influence in the management. ${ }^{1}$ Diverse surgical approaches and techniques have been described; however, controversy persists regarding the best management for these complex injuries.

The approach of traumatic injuries to the lower GI tract have come from the experience in the military setting. ${ }^{2}$ The 4Dś of damage control principles: diversion, distal rectal washout, drainage of the presacral area and direct repair; have guided the management and have led to a significant decrease in the morbidity and mortality; ${ }^{2,3}$ however, no single approach has proven to provide optimal results when dealing with these injuries.

\section{Case presentation}

A 32 yo male, was brought to our emergency department $24 \mathrm{~h}$ after receiving a high-velocity gunfire impact to the right gluteus, with an entry orifice near the anterio-superior iliac crest and an exit orifice at the perineum, leaving a blast injury in the midline of this region. Following Advanced Trauma Life Support (ATLS) protocol; primary survey revealed elevated heart rate, hypotension and signs of generalized peritonitis as well as malodorous discharge form the perineal area, Trauma team took him to the Operating Room (OR) to perform damage control surgery, where they found two small bowel lesions which where resected, as well as fecal material in the pelvis, deciding to perform a loop sigmoid colostomy and pelvic washout as well as perineal debridement with placement of a negative pressure system in the perineum and intraabdominal negative pressure system. Patient was transported to the ICU for medical management and $36 \mathrm{~h}$ after the first surgery and with the patient hemodynamically stable, the patient was taken back to the OR for a second look. During this procedure, the trauma team performed two small bowel anastomosis and during the pelvic examination we found a combined (intra and extraperitoneal) rectal wall injury in a spiral configuration starting in the anterior intraperitoneal portion of the rectal wall that continued for approximately $6 \mathrm{~cm}$ ending in the posterior extraperitoneal rectum, that, due to the complexity of the lesion, was not possible to repair through the abdomen so we decided to perform a combined (abdominal - intrarectal) approach (Fig.1). We placed a Gel Point Path Transanal Platform ${ }^{\circledR}$ (Applied Medical, Santa Margarita, CA.) to repair the extra an intraperitoneal rectal injury (Fig. 2). At

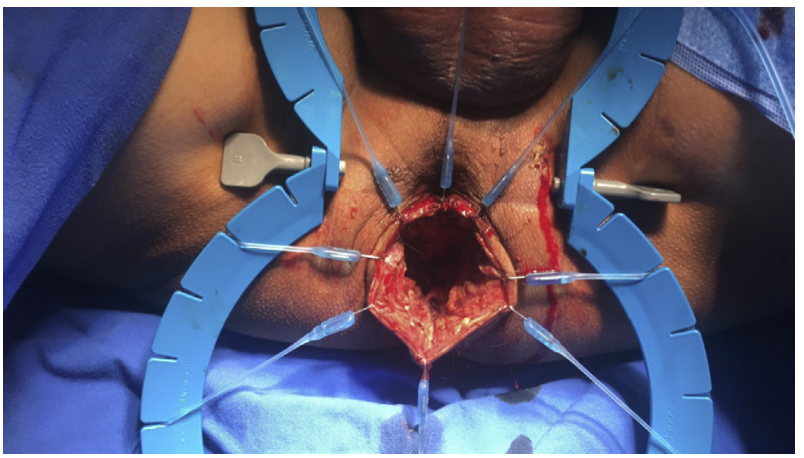

Fig. 1 - Perineal lesion.

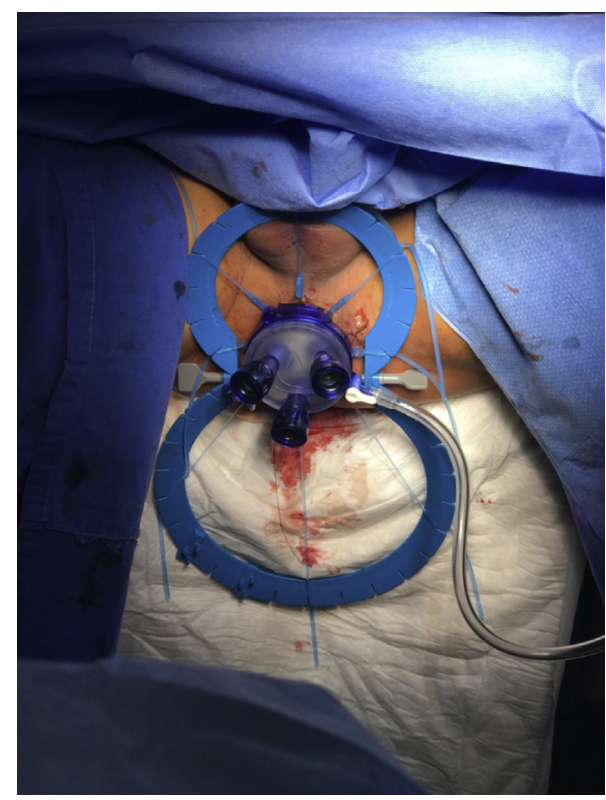

Fig. 2 - Transanal platform placement.

the beginning, we had some difficulties achieving pneumorectum due to $\mathrm{CO}_{2}$ leaking through the intraperitoneal portion of the injury, but we manage to obtain it by placing an intrarectal packing above the lesion and then we were able to perform a primary repair with a continuous running stitch with a barbed suture (Figs. 3 and 4). After complete closure of the defect we performed a pneumatic test without evidence of leak. After the rectal wall repair, we proceeded to repair the perineal injury, performing a levatorplasty obtaining adequate tissue approxi- 


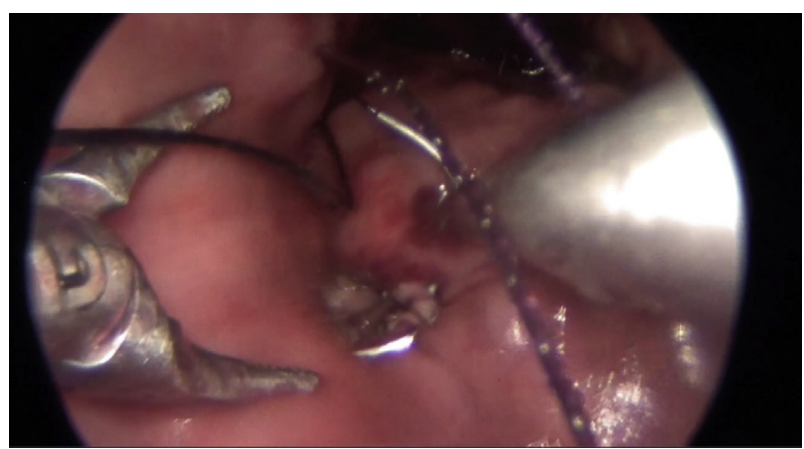

Fig. 3 - Running suture to close the defect.

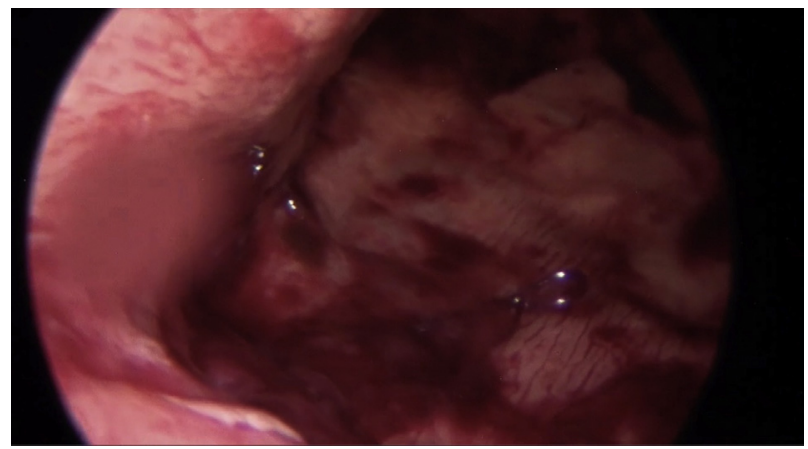

Fig. 4 - Complete closure of the combined rectal injury.

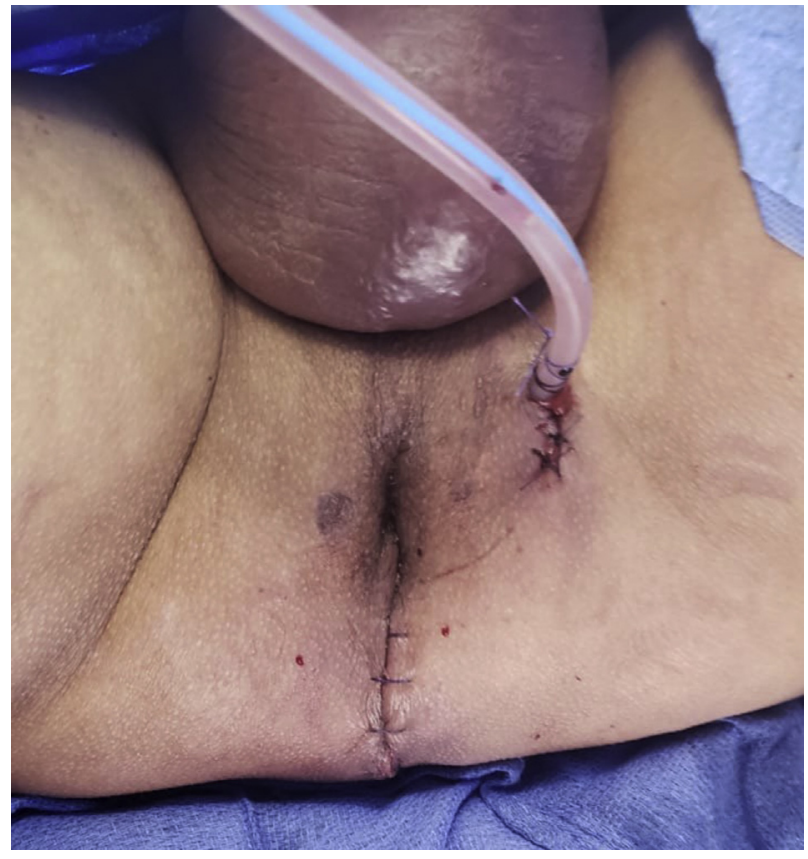

Fig. 5 - Perineal reconstruction.

mation and good aesthetic results, at that moment functional outcomes were difficult to assess (Fig. 5).

\section{Discussion}

Guidelines for the management of penetrating rectal injuries continue to evolve; with current emphasis on more con-

\begin{tabular}{|c|c|c|}
\hline Grade & Type of injury & Description of injury \\
\hline Ia & Hematoma & $\begin{array}{l}\text { Contusion or hematoma without } \\
\text { devascularization }\end{array}$ \\
\hline $\mathrm{Ib}$ & Laceration & Partial-thickness laceration \\
\hline II & Laceration & Laceration $<50 \%$ of circumference \\
\hline III & Laceration & Laceration $>50 \%$ of circumference \\
\hline IV & Laceration & $\begin{array}{l}\text { Full-thickness laceration with } \\
\text { extension into the perineum }\end{array}$ \\
\hline $\mathrm{V}$ & Vascular & Devascularized segment \\
\hline
\end{tabular}

servative approaches during the operative management (is fecal diversion necessary for nondestructive penetrating extraperitoneal rectal injuries?). The initial evaluation of any trauma patient should follow ATLS principles, where anorectal injuries are asses during the secondary survey, where digital rectal examination is mandatory but has a low value in detecting rectal injuries. ${ }^{2,4}$

Besides localization of the injury (intra or extraperitoneal), traumatic rectal injuries are classified according to the American Association of the Surgery of Trauma (AAST) Rectum Injury Scale (Table 1), as they have to be defined as destructive or non-destructive injuries ${ }^{5,6}$; however the operative decision making depends more on other factors such as: hemodynamic stability, concomitant lesions, degree of contamination and location of the injury. ${ }^{7}$

Extraperitoneal injuries are associated with higher morbidity and mortality due to delays in diagnosis, difficulty in obtaining adequate exposure and inconsistencies in suggested methods of treatment, that affect outcomes negatively. $^{7}$

For years, civilian trauma surgeons have adhered to the $4 D$ 's principles, however, several of these principles have come under scrutiny as to their benefit and efficiency in the management of penetrating rectal injuries. ${ }^{6}$

Because the location of the injury is determinant in developing clinical care guidelines for colorectal injuries, Biffl et al., proposed in 2016 a Critical Decision Algorithm and divided it into: one for colon/intraperitoneal rectum and another one for extraperitoneal rectal injuries. ${ }^{8}$

In the above-mentioned algorithm, Biffl et al., emphasize the significant differences between colonic and intraperitoneal injuries versus the ones involving the extraperitoneal rectum, proposing two different algorithms depending the location of the rectal wall lesion. The first algorithm includes intraperitoneal rectal wounds, where they reject the use of mandatory use of a derivative colostomy for this type of lesions ${ }^{9}$ and make several recommendations taking into consideration patient status and concomitant lesions. If the patient is critically ill and requires damage control laparotomy the recommendation is to control fecal spillage as quick as possible without performing a definitive repair. Whereas in patients with destructive wounds, resection and anastomosis or primary repair with or without protective stoma is recommended in patients in adequate clinical conditions. The proposed algorithm for extraperitoneal rectal wounds begins with an exam under anesthesia with rigid proctosigmoidoscopy, if there is a destructive injury $(>25 \%$ of the 
circumference) a diverting ostomy is recommended, whereas if a non-destructive injury is found primary repair with fecal diversion is recommended, whoever, despite recommendations in other surgical literature, this algorithm does not recommend the use of presacral drainage. Making an exception to this management when the extraperitoneal wound is diagnosed during laparotomy and extraperitoneal space is entered through the abdomen, suggesting in this case that, the lesion should be managed like an intraperitoneal injury. ${ }^{8}$

As suggested in the above mentioned algorithms, current surgical literature says that diversion is not recommended routinely, but it should be considered in situations where the patient is hemodynamically unstable, when the patient received 6 or more units of packed red blood cells, when intense fecal contamination of the peritoneal cavity is present or when other severe associated injuries are present. (management of colorectal injuries a western trauma association critical decision algorithm) However, a prospective multicenter study of the AAST concluded that the surgical method of the colorectal injury management was not a determinant of abdominal complications and suggested that primary anastomosis should be considered in all patients. ${ }^{10}$

Current evidence has begun to rule out the routinely use of presacral drainage as the placement of the drainage requires significant dissection and disruption of non-contaminated tissue. Available data suggests that the use of a presacral drainage leads to an increase in mortality and infectious complications. ${ }^{2,5}$ In 2016, the Eastern Association for the Surgery of Trauma guidelines recommend against the use of presacral drains.

\section{Conclusions}

The management of traumatic rectal injuries continues to evolve, changing towards more conservative approaches. Due to the low incidence of these complex pathology, medical literature is limited and consists mostly, in small retrospective studies with low level of evidence, hence, multi-institutional randomized prospective studies are necessary to assess the non-diversion/non-presacral drainage approach to the management of these injuries.
To our knowledge, this is the first report in the use of a transanal platform in trauma. In our experience, it is a challenging procedure but feasible in experienced hands. We consider that the transanal port is a valuable platform in this type of complex injuries to the rectum with excellent results.

\section{Conflicts of interest}

The authors declare no conflicts of interest.

\section{REFERENCES}

1. Navsaria PH, Edu S, Nicol AJ. Civilian extraperitoneal rectal gunshot wounds: surgical management made simpler. World J Surg. 2007;31:1347-53.

2. Lee L, McKendy KM. Management of trauma to the rectum and anus. Dis Col Rect. 2018;61:1245-8.

3. Lavenson GS, Cohen A. Management of rectal injuries. Am J Surg. 1971;122:226-30.

4. Esposito TJ, Ingraham A, Luchette FA, Sears BW, Santaniello JM, Davis KA, et al. Reasons to omit digital rectal exam in trauma patients: no fingers, no rectum, no useful additional information. J Trauma. 2005;59:1314-9.

5. Bosarge PL, Como JJ, Fox N, Falck-Ytter Y, Haut ER, Dorion HA, et al. Management of penetrating extraperitoneal rectal injuries. J Trauma. 2016;80:546-51.

6. Gonzalez RP, Phelan H, Hassan M, Ellis CN, Rodning CB. Is fecal diversion necessary for nondestructive penetrating extraperitoneal rectal injuries? J Trauma. 2006;61:815-9.

7. Velmahos GC, Gomez H, Falabella A, Demetriades D. Operative management of civilian rectal gunshot wounds: simpler is better. World J Surg. 2000;24:114-8.

8. Biffl WL, Moore EE, Feliciano DV, Albrecht RM, Croce MA, Karmy-Jones R, et al. Management of colorectal injuries. J Trauma. 2018;85:1016-20.

9. Nance ML, Nance FC. A stake through the heart of colostomy. J Trauma. 1995;39:811-2.

10. Demetriades D, Murray JA, Chan L, Ordoñez C, Bowley D, Nagy $\mathrm{KK}$, et al. Penetrating colon injuries requiring resection: diversion or primary anastomosis? an aast prospective multicenter study. J Trauma. 2001;50:765-75. 